\title{
State, Problems and Prospects in Genetic Improvement of Annual Leguminous Fodder Crops in Bulgaria
}

\author{
Georgieva ${ }^{1 *}$ and Kosev $\mathbf{V}^{2}$ \\ ${ }^{1}$ Department of technology and ecology of forage crops, Institute of Forage Crops, Bulgaria \\ ${ }^{2}$ Department of breeding of forage crops, Institute of Forage Crops, Bulgaria
}

Submission: January 30, 2017; Published: February 09, 2017

"Corresponding author: Georgieva N, Department of technology and ecology of forage crops, Institute of Forage Crops, Pleven, Bulgaria, Tel: +359887733701; Email: imnatalia@abv.bg

\begin{abstract}
Summary
Annual grain legumes continue to be important crops worldwide, both for food and feed and as rotational crops with other cultures. In grain legumes breeding programs, the selection is based mainly on yields and yield components. Grain yield of these crops is a quantitative trait which is influenced by many genetic and environmental factors. Availability of genetically diverse grain legume germ plasm allows the breeders to overcome many production limits. Preliminary genetic studies and understanding in legumes and plant genetics as a whole will open opportunities for crop improvement of these cultures.
\end{abstract}

Keywords: Annual grain legumes; Accessions; Genetic improvement; Breeding

\section{Introduction}

The role of the starting material for enhancing the effectiveness of the breeding-improved work in all crops is well known. The high effectiveness and success in the breeding are based on the use of rich genetic diversity with various valuable qualities. They serve as donors in crossing and recombination of the hereditary factors. A limited starting material and its genetic uniformity can slow down the selection process and lead to unsatisfactory results Mihov, et al. [1].

Annual legumes as peas, vetch, chickling vetch and lupine are preferred in rotations with positive impact on the subsequent crops Medvedev \& Smetannikova [2]; Ryabtseva [3]. An important additional source of nitrogen is the accumulated biological nitrogen in the soil resulting from the activity of nitrogen-fixing bacteria which utilize molecular nitrogen from the air. Thereby, during their growing period, the cultures in symbiosis with nodule bacteria enrich the soil with nitrogen Sidorov [4]; Tyutyunnikov, Fadeev, [5].

Peas (Pisum ssp.) are main legume crops that are rich in protein and with ample opportunities for use as a proper meal in humans and animals. In Bulgaria peas compared to the grain of other legume crops are most often used in feeding ruminants and monogastric animals. Peas are considered as a possible substitute for soybean meal. It is becoming an increasingly important crop in Bulgaria hardly at the beginning of XX century. Of all legumes crops it occupies the largest areas and from it are obtained higher yields of $410 \mathrm{~kg} /$ da against $286 \mathrm{~kg} /$ da for soybeans, 59 for beans $\mathrm{kg} / \mathrm{da}$ and $37 \mathrm{~kg} / \mathrm{da}$ for lens. Mainly grown are white-flowering varieties with spring type of development and low tannin content. Its contribution to organic nitrogen in the system of organic farming is indisputable and is going to increase Mihov et al. [6]; Mehandjiev et al. [7]; Krachunov et al. [8].

Soil-climatic conditions in Bulgaria enable the peas to be grown as main and intermediate crops in spring, summer and autumn. Due to its multifaceted use and large differences in soil and climatic conditions in the country, some breeding directions have been imposed - wintering varieties for grain and green mass and spring varieties for grain and green mass Kuzmova [9]. 
White lupine is the oldest culture of lupine species. It has the greatest importance for green fertilization as in this regard exceeds all other legumes. It is also drought-resistant, tolerates acid soils which are unsuitable for growing other legumes and may fix to $162 \mathrm{~kg} \mathrm{~N} /$ ha Putnam, et al. [10]; Sparrow, et al. [11]; Kurlovich, et al. [12]. Globally, there is an interest in the cultivation of white non-alkaloid lupine. In the countries of the European Union, total areas with protein crops have increased since 2004 firstly with sweet lupine which is preferred for use as fodder in the farms (LMC International, 2009). In Institute of vegetation and genetic resources (Sadovo, Bulgaria) are tested and introduced two French non-alkaloid varieties-Ljuki and Ljubljana.

Chickling vetch (Lathyrus sativus L.) is also a good nitrogenfixing crop. It can be successfully grown in the warmer and drier southern areas of the country as it is a drought-resistant crop. Except for fodder-grain and hay, chickling vetch is a good melliferous plant Sidorova, et al. [13]. Of significance is the fact that on acidic soils which has poor fertility or are quite eroded (especially in mountain and foothill regions) can be grown crops as white lupine and chickling vetch Angelova [14]. Winter vetch also shows tolerance to the acidic, alkaline and poor drained soils which defines part of its significance and value as a fodder crop McLeod [1982]; Hughes \& Metcalfe [1972].

Despite the advantages in the cultivation of these crops, there are no registered Bulgarian varieties of lupine and chickling vetch in the National Catalogue of varieties. Until now has been created one variety of winter vetch (Asko 1) and two varieties of spring vetch (Obrazets 666 and Tempo).

\section{Retrospection}

After France (1835), England (1843), Sweden (1847) and Germany (1852), Bulgaria is the fifth country in the world that initiates the beginning of agricultural researches with the creation of the First experimental field (1882) and the First Agricultural Experimental Station (1902). In 1939 in Bulgaria have been planted 10,000 acres of peas imported from Romania and in 1965 - 4, 98,000 acres of introduced and
Bulgarian varieties. The following years are sown significantly less areas, despite the increase in the needs of protein-rich fodder. Until 1964 the method of target selection was used in creating of pea varieties for green mass. During this period were selected winter varieties №5 and Pleven 2 but they did not find practical application due to their low propagation coefficient. Since 1964 as major methods are used the gender hybridization (through which are created wintering varieties Pleven 10 and Mir) and experimental mutagenesis Sachanski [15].

Lupines have not been bred in Bulgaria yet, which explains why accessions in different research collections are mainly of foreign origin. Interest in this crop is limited. Enriched and preserved collections have been stored since 1966 and serve mainly for educational and theoretical investigation purposes related to biochemical composition and changes in alkaloid content Angelova \& Stoilova [16].

Nowadays, in the gene bank of the Institute for Plant Genetic Resources (Sadovo) are registered 238 crop species of Bulgarian origin. With the largest share are fodder crops - 43, technical crops - 41, grain legumes - 34, cereals - 33, vegetables - 29, permanent crops - 39 and decorative crops - 19. The grain legume cultures, are really good predecessor, in consequence of biological nitrogen fixation which realize with them the soil bacterium, Rhizobium leguminosarum, which has the capability of fixing atmospheric nitrogen into plant-available forms and reduces the need to apply synthetic nitrogen fertilizer.

But until 2006 they are grown in small areas by reasons of due to the limited needs of livestock breeding - bean for grain (36 765 da), lentils, (19 182 da), garden pea (10 865 da), forage pea for grain (5 $700 \mathrm{da}$ ), chickpea (5 $190 \mathrm{da}$ ), soybean (899 da), and broad bean (117 da) or everything leguminous 78718 da. Despite this, in Institute of International Plant Genetic Resources is maintain composition of large grain legume collection (Table 1). Annually, in this Gene bank when evaluating plant resources of peas fodder are examined 60 indicators (according to the classifier IBPGR).

Table 1: Composition of the Bulgarian grain legume collections in Institute of Plant Genetic Resources (IPGR) - Sadovo Angelova [2015].

\begin{tabular}{|c|c|c|c|c|}
\hline \multirow{2}{*}{ Genus } & Total & $\begin{array}{c}\text { Long Term } \\
\text { Conservation }\end{array}$ & $\begin{array}{c}\text { Medium Term } \\
\text { Conservation }\end{array}$ & Working Collection \\
\hline & & & & 1120 \\
\hline Pisum & 2540 & 810 & 208 & 140 \\
\hline Lupinus & 308 & 70 & 100 & 57 \\
\hline Lathyrus & 344 & 270 & 1151 & 158 \\
\hline Vicia sp & 1880 & 777 & 220 & 35 \\
\hline Vicia faba & 702 & 467 & & \\
\hline
\end{tabular}


In the pea breeding, preferred varieties for grain are springs, white-blossoming, medium early, with a lower habitués and light-colored seeds, and for green mass varieties with purple colors, higher stems and colorful seeds Angelova [17]. The expansion of areas planted with peas and the use of diverse variety composition from farmers is only possible in an efficient and well-organized seed production. Varieties from European as well as from Bulgarian Variety Catalogue are used Angelova [18].

The problem with effectiveness of the selection work is a complex and has different aspects. It is associated with greater involvement and rational use of various genetically source material with shortening the time for obtaining new varieties and increasing the efficiency of the team in hybrid generations Mihov, et al. [19]. Until now there have been made various examinations which aimed clarification of some questions related to the genetics and the selection of peas. A rich collection is mobilized (Table 2) and a large genetic diversity of varieties and forms is created in different research centers. Intensive breeding work in fodder peas in Bulgaria is conducted in the selection centers in Sadovo, Pleven and General Toshevo (Figure 1).

Table 2: Composition of the grain legume collections in Research Institute of Forage Crops (RIFC) - Pleven.

\begin{tabular}{|c|c|}
\hline Genus & RIFC \\
\hline Pisum Sativum & 141 \\
\hline ssp. arvense & 52 \\
\hline ssp. sativum & \\
\hline
\end{tabular}

\begin{tabular}{|c|c|}
\hline Pisum sativum var. triver & 1 \\
\hline Pisum sativum var.hiemale & 5 \\
\hline Pisim sativum var. melanocarpum & 1 \\
\hline Total & 200 \\
\hline \multicolumn{2}{|l|}{ Vicia sp. } \\
\hline Vicia pannonica & 21 \\
\hline Vicia villosa & 70 \\
\hline Vicia striata & 2 \\
\hline Vicia incisa & 1 \\
\hline Vicia sativa & 3 \\
\hline Total & 97 \\
\hline \multicolumn{2}{|l|}{ Lupinus sp. } \\
\hline Lupinus albus & 40 \\
\hline Lupinus luteus & 2 \\
\hline Lupinus синя & 1 \\
\hline Lupinus червена & 1 \\
\hline Total & 44 \\
\hline \multicolumn{2}{|l|}{ Lathyrus Sativus } \\
\hline Lathyrus sativus & 16 \\
\hline \multicolumn{2}{|l|}{ Vicia Faba } \\
\hline Vicia faba & 20 \\
\hline
\end{tabular}

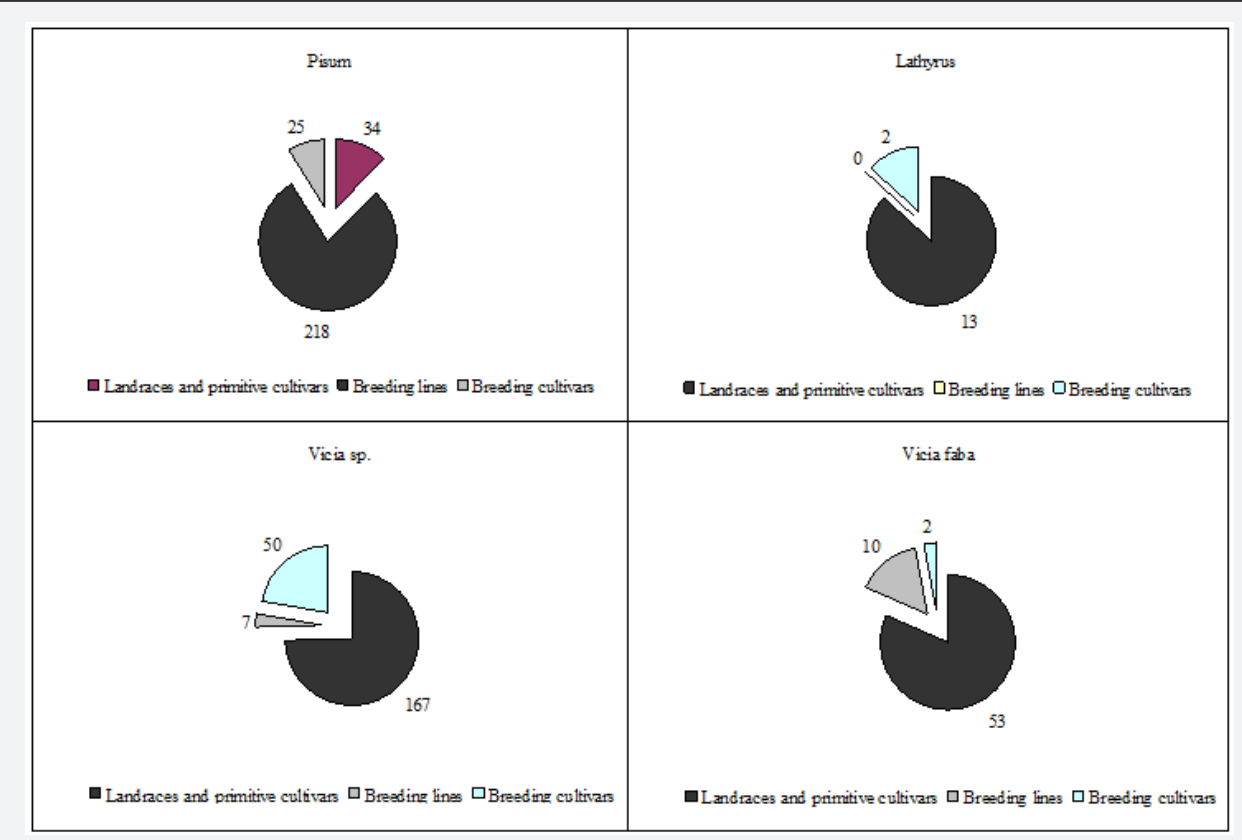

Figure 1: Inventory of grain legume collection with bulgarian origin Angelova, [2015]. 
Almost all breeding directions are developed and new technologies are applied. The selection is aimed primarily at early ripening, winter resistance and drought tolerance. Due to the climatic conditions of the country, only early-ripening and mid-ripening varieties can fully realize their productive

Table 3: Bulgarian official catalogue of forage varieties of Pisum sativum (Ministry of Agriculture and Food, Executive Agency for Variety Testing, Field Inspection and Seed Control) - 2016 year.

\begin{tabular}{|c|c|c|c|c|}
\hline Varieties & Year of Recognition & Applicant Code No & $\begin{array}{l}\text { Certificate Owner } \\
\text { Code № }\end{array}$ & $\begin{array}{l}\text { Variety Maintainer } \\
\text { Code № }\end{array}$ \\
\hline \multicolumn{5}{|c|}{ Pisum Sativum L. - Spring } \\
\hline Bohatyr & 1995 & BG 38 & c-BG 38 & BG 38 \\
\hline Amitie & 2004 & BG 2 & c-BG 2 & BG 2 \\
\hline Vokil & 2009 & 38 & & 38 \\
\hline Drujba & 2006 & BG 38 & c-BG 38 & BG 38 \\
\hline Kerpo & 2009 & 7 & c7 & 7 \\
\hline Kristal & 2004 & BG 1 & c1 & BG 1 \\
\hline Mishel & 2009 & 1 & c1 & 1 \\
\hline Pickardi & 2004 & BG 2 & c-BG 2 & BG 2 \\
\hline Pleven 4 & 2008 & BG 7 & c-BG 7 & BG 7 \\
\hline Ruse 1 & 2009 & 4 & c4 & 4 \\
\hline Tedi & 2008 & 2 & c2 & 2 \\
\hline Yatrus & 2012 & 38 & & 38 \\
\hline \multicolumn{5}{|c|}{ Pisum Sativum L. Winter } \\
\hline Vesela 23E & 2003 & BG 2 & c-BG 22 & BG 2 \\
\hline Mir & 2000 & BG 17 & c-BG17 & BG2, 7, 38 \\
\hline \multicolumn{5}{|c|}{ Vicia Sativa L. - Spring } \\
\hline Obrazets 666 & 2014 & 38 & & 38 \\
\hline Tempo & 2011 & 7 & c7 & 7 \\
\hline
\end{tabular}

The necessary genetic diversity and its use in the creation of new genotypes is implemented in different soil and climatic conditions by applying the most appropriate methods of team in hybrid and mutant populations. The method of intervarietal hybridization is associated with some difficulties due to low cross-fertilization and high labour-consumption of this process. The greatest efficiency is obtained by combining the bulk method in the early generations, after that, the following procedures are applied pedigree, single seed method and their modifications, as well as combining hybrid variability with mutational variability Mihov [1988] LMC International [22].

To improve the efficiency of the selection process in fodder peas is required to be known sufficiently the combining ability of the varieties used in combinative selection and the degree of expansion of the formative process in the hybrid variability. In this connection, there is an increasing need of studying constantly renewing starting selection material Ryabtseva NY [3], Mehandjiev, et al. [7], Koeva, et al. [23]. potential. The diversity of varieties and forms of forage peas (Table 3) includes old local varieties, populations, new varieties and lines as prevailing are selection materials Mihov, et al. [6]; Angelova [20,21]. 
3. Ryabtseva NY (2009) Some theoretical and experimental data for nitrogen-fixing nodules, formed as a result of the symbiosis of peas (Pisum sativum L.) and tuber bacteria (genus Rhizobium). Agricultural Journal of Ural 6(60): 41-44.

4. Sidorov MI (1981) Fertility and soil tillage. Voronezh: Central Chernozemski Publishing, Bulgaria, pp.3-10.

5. Tyutyunnikov AI, Fadeev VM (1984) Improving the quality of feed proteins. Rosselkhoznadzor, Russia, pp. 89-93.

6. Mihov M, Stoyanova M, Mehandjiev A (2002) Some results in the breeding of spring peas for grain (Pisum sativum L.). Jubilee session, 120 years Agricultural Science, Bulgaria, 1: 109-112.

7. Mehandjiev A, Mihov M, Noveva S, Rodeva R, Kosturkova G (2006) Some results from the investigation on genetic improvement of pea (Pisum sativum L). Field Crops Studies 3 (3): 397-403.

8. Krachunov I, Kirilov A, Ivanov K (2007) Journal of Mountain Agriculture of the Balkans 10(1): 22-29.

9. Kuzmova K (2002) Quantitative assessment of winter and spring pea varieties regarding early-ripeness. Jubilee session, 120 years Agricultural Science, Bulgaria.

10. Putnam DH, Oplinger ES, Hardman LL, Doll JD (1989) Lupine. Alternative field crops manual, University of Minnesota, USA.

11. Sparrow S, Cochran V, Sparrow E (1995) Nitrogen fixation by seven legume crops in Alaska. Agronomy Journal 87(1): 34-41.

12. Kurlovich BS, Tikhonovich IA, Kartuzova LT, Heinänen J, Kozhemykov AP, et al. (2002) Lupins (geography, classification, genetic resources and breeding). OY International North Express. Finland, pp. 269-286.

13. Sidorova KK, Levko GD, Shumny VK (2013). Investigation of nodulation and nitrogen fixation in annual species and varieties of vetchling, genus Lathyrus. Russian Journal of Genetics: Applied Research 3(3): 197-202.

14. Angelova S (2006) The protein crops are mothers of fertility. Fermer 9: 3-5.

15. Sachanski S (1988) State and future prospects in the selection of feed peas in IFC - Pleven. Agricultural Science 1: 51-55.

16. Angelova S, Stoilova T (1995) Grain legume collections in Bulgaria. In Report of a working group on grain legumes. First meeting 14-16 July 1995, Copenhagen, Denmark, pp. 28-30.

17. Angelova S (1995) Study, conservation and use of plant resources of fodder peas. Plant Sci 6: 105-107.

18. Angelova S (2005) What new in spring forage peas. Zemedelie plus 3: 9-10.

19. Mihov M, Atanasova D, Todorova R (2006) The selection as a factor to overcome various stresses at cold-resistant grain legumes. Soil Science, Agricultural Chemistry and Ecology 3: 34-39.

20. Angelova S (2008) Grain legume collection in Bulgaria. IV Balkan Symposium on Vegetables and Potatoes, Bulgaria.

21. Angelova S, Petrova S, Guteva Y, Sabeva M (2011) Sustainable preservation of indigenous south east european legumes and their traditional food and feed products. First workshop, Banja luka.

22. LMC International (2009) Evaluation of the measures of the common agricultural policy, applied to the protein crop sector. LMC InternationalOxford, pp 1-156.

23. Koeva R, Angelova S, Guteva Y (2002) Plant genetic resources and their biological potential integrated to the agricultural and ecological systems. Journal Biotechnol Biotechnol Equip 2(16): 26-35.

\section{Your next submission with Juniper Publishers will reach you the below assets}

- Quality Editorial service

- Swift Peer Review

- Reprints availability

- E-prints Service

- Manuscript Podcast for convenient understanding

- Global attainment for your research

- Manuscript accessibility in different formats

( Pdf, E-pub, Full Text, Audio)

- Unceasing customer service

Track the below URL for one-step submission https://juniperpublishers.com/online-submission.php 